\title{
ULTRASONOGRAPHIC EVALUATION OF FEMORAL CARTILAGE THICKNESS IN PATIENTS WITH POLYCYSTIC OVARY SYNDROME
}

\author{
Mustafa Kara ${ }^{1}$,Aylin Okur ${ }^{2}$ and Halil İbrahim Serin ${ }^{3}$ \\ ${ }^{1}$ Bozok University, School of Medicine, Department of Obstetrics and Gynecology, Yozgat, Turkey; \\ ${ }^{2}$ Eryaman Hastanesi, Department of Radiology, Ankara, Turkey; \\ ${ }^{3}$ Bozok University, School of Medicine, Department of Radiology, Yozgat, Turkey
}

\begin{abstract}
SUMMARY - The aim of the study was to investigate knee cartilage thickness in polycystic ovary syndrome (PCOS) patients using ultrasonography and to assess the effects of sex steroids on osteoarthritis development. A total of 90 female patients were enrolled in the study, including $47 \mathrm{pa}^{-}$ tients diagnosed with PCOS as study group and 43 patients admitted to our hospital for any other complaints as control group. Ultrasonographic evaluation of both knees was performed in all patients. The knee cartilage thickness was measured at lateral condyle, intercondylar area and medial condyle. The measurements were averaged for each region. The mean femoral cartilage thickness was greater in the study group compared with control group in all regions, with a statistically significant difference $(p<0.005)$. In conclusion, we found PCOS patients to have greater mean cartilage thickness, supporting the possible effects of sex steroids on osteoarthritis development.
\end{abstract}

Key words: Cartilage, articular; Cartilage, articular - diagnostic imaging; Polycystic ovary syndrome; Female; Knee joint; Osteoartbritis, knee

\section{Introduction}

Osteoarthritis $(\mathrm{OA})$ is a major health problem worldwide, and postmenopausal women are one of the most commonly affected groups ${ }^{1}$. Changes in sex steroid hormone levels are a risk factor for development of $\mathrm{OA}^{2}$. Besides, it is a widespread disease in reproductive age with an incidence of $4 \%-12 \%^{3}$, increased androgen levels caused by chronic anovulation, and unopposed estrogens are the major laboratory findings in polycystic ovary syndrome (PCOS) $)^{4}$. There are many studies pointing to the association of estrogen and androgen hormone levels with cartilage formation in the literature, but the relationship of these hormone levels with development of OA is still unclear. As PCOS is a useful clinical sample to investigate the effect of estro-

Correspondence to: Assoc. Prof. Mustafa Kara, PhD, Bozok University, Tip Fak Hastanesi, 6200 Yozgat, Turkey

E-mail: m.kara66@hotmail.com

Received August 25, 2017, accepted June 27, 2018 gen and androgen hormone levels on cartilage development, it may help us solve some pathophysiological questions on the development and treatment of OA.

\section{Patients and Methods}

\section{Study population}

Study subjects were recruited prospectively from female patients referred to gynecology and orthopedics departments from June to November, 2014. Patients diagnosed with PCOS were selected as study group. Control group included patients with various complaints, admitted to our radiology department for knee ultrasonography (US) examination. The diagnosis of PCOS was made according to the Rotterdam criteria of the American Society of Reproductive Medicine (ASRM) ${ }^{5}$, with evaluation of the presence of oligo/amenorrhea, clinical and biochemical signs of hyperandrogenism, and sonographic confirmation of 
PCOS. To rule out the possible differences between the groups, all patients were questioned about chronic drug use, smoking, previous knee operations, or trauma. Fertility status and demographic parameters of age, height and weight were also recorded. After careful exclusion, 47 fertile women with PCOS and 43 fertile women without PCOS, matched for age and body mass index (BMI), were enrolled in the study. All patients signed the informed consent form for participation in the study, which received institutional ethical approval and was conducted in line with the Declaration of Helsinki principles.

\section{Ultrasonographic measurements of femoral cartilage}

Thickness of the femoral articular cartilage was measured by Aloca Prosound A6 (Hitachi Aloca Medical, USA) equipped with a $7.5 \mathrm{MHz}$ linear array imaging probe. All measurements were performed by the same radiologists blinded for the patient clinical status while the patient was sitting comfortably on the examination table with the knees in maximum flexion. The probe was placed in the axial plane in the suprapatellar area. Three midpoint measurements were taken from each knee, i.e. from the right lateral condyle, right intercondylar area, right medial condyle, left medial condyle, left intercondylar area and left lateral condyle (Fig. 1).

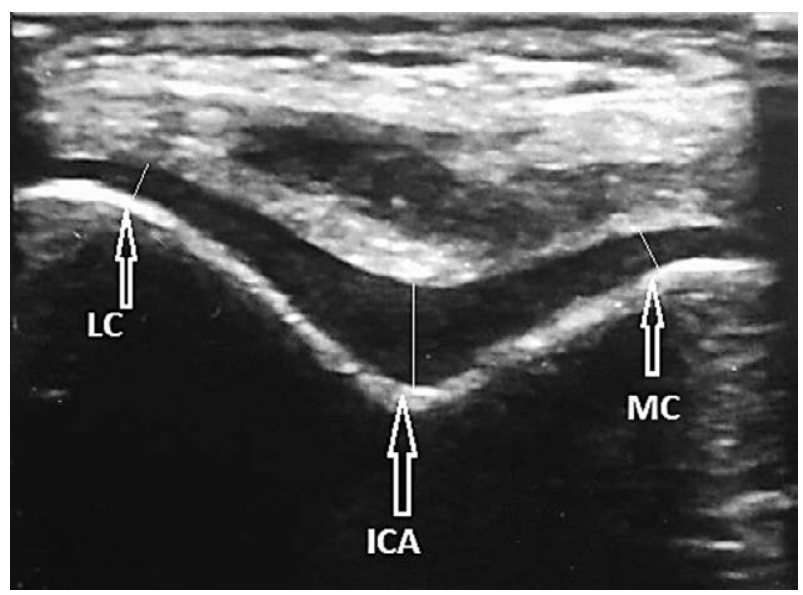

Fig. 1. Ultrasonographic image demonstrating femoral cartilage measurements (suprapatellar axial view).

$\mathrm{LCL}=$ lateral condyle; $\mathrm{IA}$ = intercondylar area; $\mathrm{MC}$ = medial condyle

\section{Statistical analysis}

All statistical analyses were carried out using the SPSS software program. Categorical variables were compared using the $\chi^{2}$-test or Fisher exact test, whereas Student's t test, Mann-Whitney U test and KruskalWallis test were employed to compare the groups. A p value of less than 0.05 was considered statistically significant.

\section{Results}

There was no significant difference between the groups in their demographic data (Table 1). Measurements of 94 knees in the study group and 86 knees in the control group were analyzed. The mean femoral cartilage thickness at all measurement sites was higher in the study group compared with control group, yielding statistical significance $(\mathrm{p}<0.05)$. These results are shown in Table 2.

Table 1. Demographic data of patients

\begin{tabular}{|l|l|l|l|}
\hline & Study group & Control group & $\mathrm{p}$ \\
\hline Age (yrs) & $24 \pm 3.6$ & $25.8 \pm 3.1$ & 0.512 \\
Height & $64 \pm 2.9$ & $174 \pm 3.1$ & 0.684 \\
Weight & $65 \pm 3.2$ & $178 \pm 4.1$ & 0.612 \\
BMI & $22 \pm 1.9$ & $23 \pm 2.1$ & 0.618 \\
\hline
\end{tabular}

$\mathrm{BMI}=$ body mass index; $\mathrm{p}=$ level of significance

Table 2. Femoral cartilage thickness of patients

\begin{tabular}{|l|l|l|l|}
\hline & $\begin{array}{l}\text { Study group } \\
(\mathrm{n}=47)\end{array}$ & $\begin{array}{l}\text { Control group } \\
(\mathrm{n}=43)\end{array}$ & $\mathrm{p}$ \\
\hline RLC & $2.00 \pm 0.41$ & $1.76 \pm 0.33$ & 0.003 \\
RIA & $2.12 \pm 0.51$ & $1.99 \pm 0.45$ & 0.002 \\
RMC & $2.15 \pm 0.51$ & $2.01 \pm 0.22$ & 0.004 \\
LLC & $2.03 \pm 0.31$ & $1.812 \pm 0.55$ & 0.003 \\
LIA & $2.06 \pm 0.28$ & $1.87 \pm 0.33$ & 0.002 \\
LMC & $2.20 \pm 0.41$ & $2.01 \pm 0.12$ & 0.003 \\
\hline
\end{tabular}

$\mathrm{p}=$ level of significance; $\mathrm{RLC}=$ right lateral condyle; $\mathrm{RIA}=$ right intercondylar area; $\mathrm{RMC}=$ right medial condyle; $\mathrm{LMC}=$ left medial condyle; LIA = left intercondylar area; LLC = left lateral condyle

\section{Discussion}

Polycystic ovary syndrome is a common endocrinopathy in reproductive age with an incidence of $4 \%$ to $7 \%^{6}$, reaching $15 \%$ in infertile patients ${ }^{7}$. The main biochemical findings are unopposed levels of estradiol and higher luteinizing hormone/follicle-stimulating 
hormone ratios, in addition to androgen excess, and these endocrine disorders result in chronic anovulation ${ }^{8}$. The anovulation induces hormonal imbalance and the patient clinical status enters a vicious circle. In this respect, we believed that patients diagnosed with PCOS might provide an appropriate clinical sample to investigate the possible effects of sex steroids on cartilage thickness and $\mathrm{OA}$ formation.

Tsai and $\mathrm{Liu}^{9}$ report that sex steroids have physiological effects on cartilage involvement, and Abu et $a l .{ }^{10}$ showed that there were sex steroid receptors located on articular chondrocytes. Previous data indicate that estrogen may conflict with osteoclast and osteoblast coupling and thus the cartilage turnover; it also affects the osteoblast activity on subchondral bone and cartilage via second messengers such as transforming growth factor-beta, cartilage-inducing factor $\mathrm{A}$, interleukin-6, and insulin-like growth factor I and $\mathrm{II}^{9,11-13}$. Additionally, previous data suggest that estrogen replacement therapy used for more than 5 years resulted in increased knee cartilage volume ${ }^{13}$, and exogenous estrogen was shown to exert some beneficial effects on OA treatment in animal models ${ }^{14,15}$. However, it is known that men have greater cartilage volume compared with women; we could not assess androgen effects on cartilage volume because of the study population selection. None of our patients showed an androgenic phenotype and further studies are needed to explore the possible impact of androgens on the knee cartilage in PCOS. Another limitation of our study was that our patients had higher BMI values. Since higher weight has an important role in OA formation, our results could not be interpreted as suggesting that PCOS patients had a lower risk of developing OA later in life. We believe that our ongoing long-term follow-up study of PCOS patients will provide answer to this problem.

Since the patients diagnosed with PCOS have greater mean cartilage thickness, we are inclined to believe that the pathophysiological mechanism is based on increased androgen and estrogen hormone values in these patients. Hormone replacement treatment may be useful for OA patients, but further studies are needed to prove our hypothesis.

\section{References}

1. Eryılmaz ÖG, Kara M, Tiftik T, Aksakal FN, Uzunlar Ö, Su FA, Mollamahmutoğlu L, Özçakar L. Ultrasonographic measurement of the femoral cartilage thickness in patients with polycystic ovary syndrome Fertil Steril. 2012 Jan;97(1):235-7.

2. Wluka AE, Davis SR, Bailey M, Stuckey SL, Cicuttini FM. Users of oestrogen replacement therapy have more knee cartilage than non-users. Ann Rheum Dis. 2001 Apr;60(4):332-6.

3. Şahmay S, Atakul N. Polikistik over sendromu. Turkiye Klinikleri J Fam Med-Special Topics. 2013;4.6:56-64. (in Turkish)

4. Goldzieher JW, Green JA. The polycystic ovary I. Clinical and histological features. J Clin Endocrinol Metab. 1961;22: 325-38.

5. Rotterdam ESHRE/ASRM-Sponsored PCOS Consensus Workshop Group. Revised 2003 consensus on diagnostic criteria and long-term health risks related to polycystic ovary syndrome. Fertil Steril. 2004;81:19-25.

6. Moran C, Tena G, Moran S, Ruiz P, Duque X. Prevalence of polycystic ovary syndrome and related disorders in Mexican women. Gynecol Obstet Invest. 2010;69:274-80.

7. Badawy A, Elnashar A. Treatment options for polycystic ovary syndrome. Int J Womens Health. 2011;3:25-35.

8. Tena G, Moran C, Romero R, Moran S. Ovarian morphology and endocrine function in polycystic ovary syndrome. Arch Gynecol Obstet. Published online January 18, 2011.

9. Tsai CL, Liu TK. Osteoarthritis in women: its relationship to estrogen and current trends. Life Sci. 1992;50:1737-44.

10. Abu EO, Horner V, Kusec V, Triffitt JT, Compston JE. The localization of androgen receptors in human bone. J Clin Endocrinol Metab. 1997;82:3493.

11. Fernihough JK, Richmond RS, Carlson CS, Cherpes T, Holly JMP, Loeser RF. Estrogen replacement therapy modulation of the insulin-like growth factor system in monkey knee joints. Arthritis Rheum. 1999;42:2103-11.

12. Guerne PA, Carson D, Lotz M. IL-6 production by human chondrocytes: modulation of its synthesis by cytokines, growth factors and hormones in vitro. J Immunol. 1990;144:494-505.

13. Wluka AE, Davis SR, Bailey M, Stuckey SL, Cicuttini FM. Users of oestrogen replacement therapy have more knee cartilage than non-users. Ann Rheum Dis. 2001;60:332-6.

14. Rosner IA, Goldberg VM, Getzy L, Moskowitz RW. Effects of estrogen on cartilage and experimentally induced osteoarthritis. Arthritis Rheum. 1979;22:52-8.

15. Turner AS, Athanasiou KA, Zhu CF, Alvis MR, Bryant HU. Biochemical effects of estrogen on articular cartilage in ovariectomized sheep. Osteoarthritis Cartilage. 1997;5:63-9. 
Sažetak

\section{ULTRAZVUČNA PROCJENA DEBLJINE BEDRENE HRSKAVICE U BOLESNICA SA SINDROMOM POLICISTIČNIH JAJNIKA}

\section{Kara, A. Okur i H.I. Serin}

Cilj istraživanja bio je ultrazvučno procijeniti debljinu hrskavice koljena u bolesnica sa sindromom policističnih jajnika (SPCJ) i učinak spolnih hormona na razvoj osteoartritisa. U istraživanje je bilo uključeno ukupno 90 žena, tj. 47 bolesnica s dijagnozom SPCJ kao ispitna skupina i 43 bolesnice primljene na odjel zbog drugih tegoba kao kontrolna skupina. Ultrazvučna procjena obaju koljena učinjena je u svih bolesnica. Debljina hrskavice koljena mjerena je u lateralnom kondilu, interkondilarnom području i medijalnom kondilu te je izračunat prosjek mjerenja za svaku regiju. Srednja debljina koljenske hrskavice bila je veća u ispitnoj skupini u usporedbi s kontrolnom skupinom u svim regijama, a razlika je bila statistički značajna $(\mathrm{p}<0,005)$. Dakle, utvrđeno je da bolesnice sa SPCJ imaju veću srednju debljinu koljenske hrskavice, što govori u prilog mogućeg utjecaja spolnih hormona na razvoj osteoartritisa.

Ključne riječi: Hrskavica, zglobna; Hrskavica, zglobna - dijagnosticko snimanje; Policistični ovarij, sindrom; Ženska osoba; Koljenski zglob; Osteoartritis koljena 